\title{
PREPARATION AND EVALUATION OF DIAGNOSTIC KITS OF NEWCASTLE DISEASE: INFECTIOUS BRONCHITIS AND INFECTIOUS BURSAL DISEASE
}

\author{
Noura, F. Alkhalefa"; Albagory,G.F."; Mansour, A.A." and Khodeir, M.H." \\ "Faculty of Veterinary Medicine, Kafrelsheikh University \\ "* Faculty of Veterinary Medicine, Banha University \\ Veterinary Serum and Vaccine Research Institute, Abbasia, Cairo
}

\begin{abstract}
The present study was designed to prepare $N D, I B$ and IBD anti sera conjugated with fluorescine isothiocyanate and horse radish peroxidase to be available on request as local products saving time and cost. The obtained results indicated that the prepared Newcastle Disease (NDV); Infectious Bronchitis (IBV) and Infectious Bursal Disease (IBDV) antisera either in simple forms or conjugated forms with fluorescine isothiocyanate and horse radish peroxidase are of high quality providing local kits of low cost and on time of request for diagnostic and confirmatory serological tests.
\end{abstract}

In addition, preparation of antisera in goats, which need less husbandry requirements than those required for chicken or rabbits, provide huge amounts of such kits in comparison with those prepared in other hosts, the thing which helps to decrease the cost.

\section{INTRODUCTION}

It is well known that successful control and eradication of infectious diseases depend mainly on accurate diagnosis that depends on application of sensitive, accurate and rapid serological tests. These tests often need specific anti-sera (hyper immune sera containing the specific antibodies) 
either in necked form (for agar gel precipitation test and virus neutralization test) or in conjugated forms with flourescine isothiocyanate (for fluorescent antibody technique) or with horse radish peroxidase (for enzyme linked immune sorbent assay).

Antibodies are useful for specifically recognizing antigens and the detection of antigen-antibody complex could be easy when precipitation occurs. Labeling of antibodies make antigen identification easier.

Specific, rapid and sensitive serological tests like fluorescent antibody technique (FAT) and enzyme linked immune sorbent assay (ELISA) are required for accurate diagnosis of infectious agents to reach to well applicable control measures. FAT depends mainly on antigenantibody reaction in the presence of a fluorescent dye (flourescin isothiocyanate "FITC") which irradiates with ultraviolet light emitting apple green flourescence (Tizard, 1996). The technique depends on the presence of specific antiserum conjugated with FITC. FAT has gained wide acceptance in virology serving for many purposes such as the detection of cellular localization of viral antigens (Spendlove et al, 1963); establishment of temporal sequence after infection appearance (Breitenfeld and Schafer, 1957); and detection of virus infected cells which fail to produce viral progeny and still synthesize virus coded antigens which continue to harbor viral genetic material (Tevethia et al, 1965).

The present study was designed to prepare specific hyper-immune sera against NDV; IBV and IBDV in necked forms and in forms conjugated with flourescine isothiocyanate and horse radish peroxidase to be available on request as local kits avoiding the high cost and long time needed to provide the imported kits. It was taken in consideration to 
prepare such anti-sera in different hosts (rabbits, chickens, ducks and goats) to chose and determine the most suitable host (from the quality and economic point of view). The obtained anti-sera (either in necked or conjugated forms) are evaluated through the application of HI; AGPT; SNT; FAT and ELIZA.

\section{MATERIAL AND METHODS}

\section{1- Vaccines:}

Inactivated oil adjuvant Newcastle disease (ND) vaccine (Lasota strain of a titer $10^{9} \mathrm{EID}_{50} / \mathrm{ml}$ ); infectious bronchitis (IB) live attenuated vaccine (Massachusetts $\mathrm{H}_{120}$ strain of a titer $10^{8.5} \quad \mathrm{EID}_{50} / \mathrm{ml}$ ) and infectious bursal disease (IBD) vaccine (D78 strain of a titer $10^{8.5}$ EID $_{50} / \mathrm{ml}$ ) were supplied kindly by Veterinary Serum and Vaccine Research Institute, Abbasia, Cairo. These vaccines were used for preparation of ND; IB and IBD anti-sera in different hosts.

\section{2- Viruses:}

Vero cell culture adapted strains of ND, IB and IBD viruses were kindly supplied by Veterinary Serum and Vaccine Research Institute, Abbasia, Cairo. These viruses had titers of $10^{6.5} ; 10^{6}$ and $10^{7} \mathrm{TCID}_{50} / \mathrm{ml}$ respectively. They were used in serum neutralization test (SNT) and in preparation of viral antigens to be used in ELISA.

\section{3- Infected cell cultures:}

Vero cells were cultured on cover slips in Leighton's tubes in four groups; the first one was infected with NDV and the second one was infected with IBV while the third group was infected with IBDV. The fourth group of cell cultured cover slips was kept without infection as control. On the $2^{\text {nd }}$ day post infection these cell cultures were fixed with 
child acetone and subjected to direct fluorescent antibody technique using the corresponding prepared conjugated antiserum

\section{4- Virus antigens:}

$\mathrm{ND}, \mathrm{IB}$ and IBD virus antigens were prepared in vero cell cultures according to Lefevre and Diallo (1990) to be used for the evaluation of the prepared anti-sera conjugated with horse radish peroxidase using ELISA.

\section{5- Experimental animals:}

Fifteen of each healthy Bosket rabbits of about $3 \mathrm{~kg}$ body weights; SPF chickens of about $2 \mathrm{Kg}$ body weights; ducks of about $2.5-3 \mathrm{Kg}$ body weights and three goats were used for preparation of NDV, IBV and IBDV anti-sera. In addition three of each species were kept as test control. These animals were housed under hygienic measures in separate isolates receiving balanced ration and adequate water. Five hosts of each species were used for preparation of each antiserum.

\section{6- Chicken RBCs:}

Chicken red blood corpuscles were obtained from health chickens and diluted to be $1 \%$ to be used in $\mathrm{HI}$ according to Allan et al (1978).

\section{7- Cell culture:}

African green monkey kidney cell line (vero) established by Yasumara and Kaowatika (1963) were used in serum neutralization test and preparation of virus antigens. These cell cultures were supplied by the department of Pet Animal Vaccine Research, Vet. Ser. Vac. Res. Inst. Abbasia, Cairo, Egypt. 
8- Chemicals used for conjugation of the prepared anti-sera with Fluorescein isothiocyanate $\left(\mathrm{C}_{4} \underline{\mathrm{H}}_{11} \underline{\mathrm{NO}}_{5} \underline{\mathrm{S}) \mathrm{E}}\right.$ :

$\left(\mathrm{C}_{4} \mathrm{H}_{11} \mathrm{NO}_{5} \mathrm{~S}\right) \mathrm{E}$ was supplied by Merck, Darmstadt for Microscopy (M.Gew.389.39).

9- Chemicals and reagents used for conjugation of the prepared antisera with horse radish peroxidase (HRP):

A- HRP product number p-8375 type VI, lot 25C-9510 was supplied by Sigma Chemical Company. It had an activity of 365 purogallin units/mg.

B- Sodium borohydride $\left(\mathrm{NaBH}_{4}\right)$ was supplied by S.D. fine chemical LTD Company; Chemical Manufacturing Division Fair, Lawn, New Jersey. It had a molecular weight of 105.99.

C- Sodium periodate $\left(\mathrm{NaIO}_{4}\right)$.

10- Standard anti-sera conjugated with hors radish peroxidase and fluorescein isothiocyanate:

These conjugates were supplied by the Veterinary Serum and Vaccine Research Institute, Abbasia, Cairo, and used in a comparison with the prepared conjugates to evaluate their efficacies.

\section{1- Preparation of ND, IB and IBD hyper-immune sera:}

Hyper-immune sera against ND, IB and IBD viruses were prepared using the different vaccines according to the method described by Ihemelanadu et al (1985). 


\section{2- Serum neutralization test (SNT):}

Both qualitative and quantitative SNT were carried out using the micro titer technique according to Rossiter et al (1985) and the titer of serum neutralizing antibodies was calculated as the reciprocal of the final serum dilution which neutralized and inhibited the CPE of 100-200 $\mathrm{TCID}_{50}$ of the used virus according to Singh, et al (1967).

\section{3- Haemagglutination (HA) and Haemagglutination inhibition (HI) tests:}

HA and HI tests were carried out according to Allan et al (1978).

\section{4- Agar gel precipitation test (AGPT):}

The test was carried out according to Cowan and Graves (1966).

\section{5- Precipitation of the immunoglobulin of the prepared antiserum:}

It was carried out using ammonium sulphate according to Narin and Marrack (1964). The globulin content was estimated according to Weichselbaum (1946) and adjusted to be $20 \mathrm{mg} / \mathrm{ml}$ using phosphate buffer saline.

16- Conjugation of the prepared anti-sera with Fluorescein isothiocyanate:

It was done according to the method of Narin (1969).

17- Conjugation of the prepared ND, IB and IBD antisera with HRP:

It was carried out following up the method described by Tijssen and Kurstak (1984). 


\section{8- Preparation of viral antigen:}

Preparation of ND, IB and IBD viral antigens was carried out according to Brian and Hiller (1996) from infected Vero cells. These antigens were used in ELISA to evaluate the prepared conjugates with horse radish peroxides.

\section{9- Direct fluorescent antibody technique (FAT):}

Direct FAT was carried out on infected Vero cells with ND, IB and IBD viruses to evaluate the prepared antisera conjugated with fluorescine isothiocyanate. The technique was carried out according to Soliman et al (1989).

\section{0- Checkboard and Direct ELISA:}

To determine the amount of antigen added during the coating procedure which uptake specific antibodies, a modified checkerboard titration was used according to the comminuted methods of Hubschle et al (1981) and direct ELISA was carried out according to Voller et al (1976).

\section{RESULTS AND DISCUSSION}

The obtained results could be summarized in the following tables and figures.

Table (1): NDV antibody titer in prepared anti-sera.

\begin{tabular}{||c||c|c|c||}
\hline \multirow{2}{*}{ Prepared antiserum in } & \multicolumn{3}{|c|}{ ND antibody titer $(\log 2 /$ ml $)$ using } \\
\cline { 2 - 4 } & HI test & SNT & AGPT \\
\hline \hline Chickens & 9 & 8 & 8 \\
\hline Ducks & 8 & 7 & 7 \\
\hline Rabbits & 8 & 7 & 7 \\
\hline Goats & 9 & 9 & 8 \\
\hline
\end{tabular}

Kafrelsheikh Vet. Med. J. Vol. 7 No. 1 (2009) 
Noura, F. Alkhalefa et al.,

Table (2): IBV antibody titer in prepared anti-sera.

\begin{tabular}{|c||c|c||}
\hline \multirow{2}{*}{ Prepared antiserum in } & \multicolumn{2}{|c|}{ IB antibody titer $(\log 2 / \mathbf{m l})$ using } \\
\cline { 2 - 3 } & SNT & AGPT \\
\hline \hline Chickens & 9 & 8 \\
\hline Ducks & 4 & 6 \\
\hline Rabbits & 8 & 6 \\
\hline Goats & 7 & 3 \\
\hline
\end{tabular}

Table (3): IBDV antibody titer in prepared anti-sera.

\begin{tabular}{|c||c|c||}
\hline \multirow{2}{*}{ Prepared antiserum in } & \multicolumn{2}{|c||}{ IBD antibody titer $(\log 2 / \mathrm{ml})$ using } \\
\cline { 2 - 3 } & SNT & AGPT \\
\hline Chickens & 8 & 8 \\
\hline Ducks & 7 & 6 \\
\hline Rabbits & 8 & 8 \\
\hline Goats & 7 & 7 \\
\hline
\end{tabular}

Table (4): Evaluation of the prepared anti ND virus hyper-immune serum conjugated with FITC.

\begin{tabular}{|c|c|c|c|c|c|c|c|c|}
\hline \multirow{3}{*}{$\begin{array}{c}\text { Tested } \\
\text { conjugate } \\
\text { dilution }\end{array}$} & \multicolumn{8}{|c|}{ Tested conjugate prepared in } \\
\hline & \multicolumn{2}{|c|}{ Chickens } & \multicolumn{2}{|c|}{ Ducks } & \multicolumn{2}{|c|}{ Rabbits } & \multicolumn{2}{|c|}{ Goats } \\
\hline & $\mathbf{A}^{*}$ & IC $* *$ & $\mathbf{A}$ & IC & $\mathbf{A}$ & IC & $\mathbf{A}$ & IC \\
\hline $1: 10$ & $4+$ & $4+$ & $4+$ & $4+$ & $4+$ & $4+$ & $4+$ & $4+$ \\
\hline $1: 100$ & $4+$ & $4+$ & $4+$ & $4+$ & $4+$ & $4+$ & $4+$ & $4+$ \\
\hline $1: 1000$ & $4+$ & $4+$ & $3+$ & $3+$ & $4+$ & $4+$ & $4+$ & $4+$ \\
\hline $1: 10000$ & $3+$ & $3+$ & $2+$ & $2+$ & $3+$ & $3+$ & $4+$ & $4+$ \\
\hline 1:100000 & - & - & - & - & $2+$ & $2+$ & $3+$ & $3+$ \\
\hline $1: 1000000$ & - & - & - & - & - & - & - & - \\
\hline
\end{tabular}

$* \mathrm{~A}=$ antigen

$4+=$ Strong positive reactions.

$+=$ Weak positive reactions.
$* * \mathrm{IC}=$ infected cell culture

$2,3+=$ Moderate positive reactions.

-= Negative reactions.

Kafrelsheikh Vet. Med. J. Vol. 7 No. 1 (2009) 
Preparation And Evaluation Of Diagnostic Kits Of ...

Table (5): Evaluation of the prepared anti IB virus hyper-immune serum conjugated with FITC

\begin{tabular}{|c|c|c|c|c|c|c|c|c|}
\hline \multirow{3}{*}{$\begin{array}{c}\text { Tested } \\
\text { conjugate } \\
\text { dilution }\end{array}$} & \multicolumn{8}{|c|}{ Tested conjugate prepared in } \\
\hline & \multicolumn{2}{|c|}{ Chickens } & \multicolumn{2}{|c|}{ Ducks } & \multicolumn{2}{|c|}{ Rabbits } & \multicolumn{2}{|c|}{ Goats } \\
\hline & $\mathbf{A}^{*}$ & IC $* *$ & $\mathbf{A}$ & IC & $\mathbf{A}$ & IC & $\mathbf{A}$ & IC \\
\hline $1: 10$ & $4+$ & $4+$ & $4+$ & $4+$ & $4+$ & $4+$ & $4+$ & $4+$ \\
\hline $1: 100$ & $4+$ & $4+$ & $4+$ & $4+$ & $4+$ & $4+$ & $4+$ & $4+$ \\
\hline $1: 1000$ & $3+$ & $3+$ & $2+$ & $2+$ & $4+$ & $4+$ & $4+$ & $4+$ \\
\hline $1: 10000$ & $2+$ & + & - & - & $3+$ & $3+$ & $4+$ & $4+$ \\
\hline $1: 100000$ & - & - & - & - & + & + & $2+$ & $2+$ \\
\hline $1: 1000000$ & - & - & - & - & - & - & - & - \\
\hline \multicolumn{5}{|l|}{$* A=$ antigen } & \multicolumn{4}{|c|}{$* * \mathrm{IC}=$ infected cell culture } \\
\hline \multicolumn{5}{|c|}{$4+=$ Strong positive reactions. } & \multicolumn{4}{|c|}{$2,3+=$ Moderate positive reactions. } \\
\hline \multicolumn{5}{|c|}{ += Weak positive reactions. } & \multicolumn{4}{|c|}{-= Negative reactions. } \\
\hline
\end{tabular}

Table (6): Evaluation of the prepared anti IBD virus hyper-immune serum conjugated with FITC.

\begin{tabular}{|c|c|c|c|c|c|c|c|c|}
\hline \multirow{3}{*}{$\begin{array}{c}\text { Tested } \\
\text { conjugate } \\
\text { dilution }\end{array}$} & \multicolumn{8}{|c|}{ Tested conjugate prepared in } \\
\hline & \multicolumn{2}{|c|}{ Chickens } & \multicolumn{2}{|c|}{ Ducks } & \multicolumn{2}{|c|}{ Rabbits } & \multicolumn{2}{|c|}{ Goats } \\
\hline & $\mathbf{A}^{*}$ & $\mathrm{IC}^{* * *}$ & $\mathbf{A}$ & IC & $\mathbf{A}$ & IC & $\mathbf{A}$ & IC \\
\hline $1: 10$ & $4+$ & $4+$ & $4+$ & $4+$ & $4+$ & $4+$ & $4+$ & $4+$ \\
\hline $1: 100$ & $4+$ & $4+$ & $4+$ & $4+$ & $4+$ & $4+$ & $4+$ & $4+$ \\
\hline $1: 1000$ & $4+$ & $4+$ & $4+$ & $4+$ & $4+$ & $4+$ & $4+$ & $4+$ \\
\hline 1:10000 & $3+$ & $3+$ & $2+$ & $2+$ & $4+$ & $4+$ & $4+$ & $4+$ \\
\hline $1: 100000$ & $2+$ & $2+$ & + & + & $2+$ & $2+$ & $3+$ & + \\
\hline $1: 1000000$ & - & - & - & - & - & - & + & + \\
\hline \multicolumn{5}{|l|}{$* A=$ antigen } & \multicolumn{4}{|c|}{${ }^{*} * \mathrm{IC}=$ infected cell culture } \\
\hline \multicolumn{5}{|c|}{$4+=$ Strong positive reactions. } & \multicolumn{4}{|c|}{$2,3+=$ Moderate positive reactions } \\
\hline \multicolumn{3}{|c|}{$+=$ Weak positive reactions. } & & & \multicolumn{4}{|c|}{-= Negative reactions. } \\
\hline
\end{tabular}

Kafrelsheikh Vet. Med. J. Vol. 7 No. 1 (2009) 
Noura, F. Alkhalefa et al.,

Table (7): Check board ELISA.

\begin{tabular}{|c||c|c|c|}
\hline \multirow{2}{*}{ Antigen dilution } & \multicolumn{3}{|c|}{ Tested antigen } \\
\cline { 2 - 4 } & ND & IB & IBD \\
\hline \hline $1: 1000$ & + & + & + \\
\hline $1: 2000$ & + & + & + \\
\hline $1: 3000$ & + & + & + \\
\hline $1: 4000$ & + & + & + \\
\hline $1: 5000$ & + & - & - \\
\hline $1: 6000$ & - & - & + \\
\hline
\end{tabular}

Table (8): Titer of the prepared anti ND virus hyper-immune serum conjugated with horse radish peroxidase using direct ELISA

\begin{tabular}{|c||c|c|c|c|}
\hline \multirow{2}{*}{ Conjugate Dilution } & \multicolumn{4}{|c|}{ Conjugate serum prepared in } \\
\cline { 2 - 5 } & Chickens & Ducks & Rabbits & Goats \\
\hline \hline $1: 100$ & + & + & + & + \\
\hline $1: 200$ & + & + & + & + \\
\hline $1: 300$ & + & + & + & + \\
\hline $1: 400$ & + & + & + & + \\
\hline $1: 500$ & + & - & + & - \\
\hline $1: 600$ & - & - & - & - \\
\hline
\end{tabular}

Table (9): Titer of the prepared anti IB virus hyper-immune serum conjugated with horse radish peroxidase using direct ELISA.

\begin{tabular}{|c|c|c|c|c|}
\hline \multirow{2}{*}{ Conjugate Dilution } & \multicolumn{4}{|c|}{ Conjugate serum prepared in } \\
\hline & Chickens & Ducks & Rabbits & Goats \\
\hline 1:100 & + & + & + & + \\
\hline 1:200 & + & + & + & + \\
\hline $1: 300$ & + & + & + & + \\
\hline 1: 400 & + & + & + & + \\
\hline $1: 500$ & + & - & + & - \\
\hline $1: 600$ & - & - & - & - \\
\hline
\end{tabular}

Table (10): Titer of the prepared anti IBD virus hyper-immune serum conjugated with horse radish peroxidase using direct ELISA.

\begin{tabular}{|c|c|c|c|c|}
\hline \multirow{2}{*}{ Conjugate Dilution } & \multicolumn{4}{|c|}{ Conjugate serum prepared in } \\
\hline & Chickens & Ducks & Rabbits & Goats \\
\hline 1:100 & + & + & + & + \\
\hline $1: 200$ & + & + & + & + \\
\hline $1: 300$ & + & + & + & + \\
\hline 1:400 & + & + & + & + \\
\hline $1: 500$ & + & - & + & - \\
\hline $1: 600$ & - & - & - & - \\
\hline
\end{tabular}


Preparation And Evaluation Of Diagnostic Kits Of ...

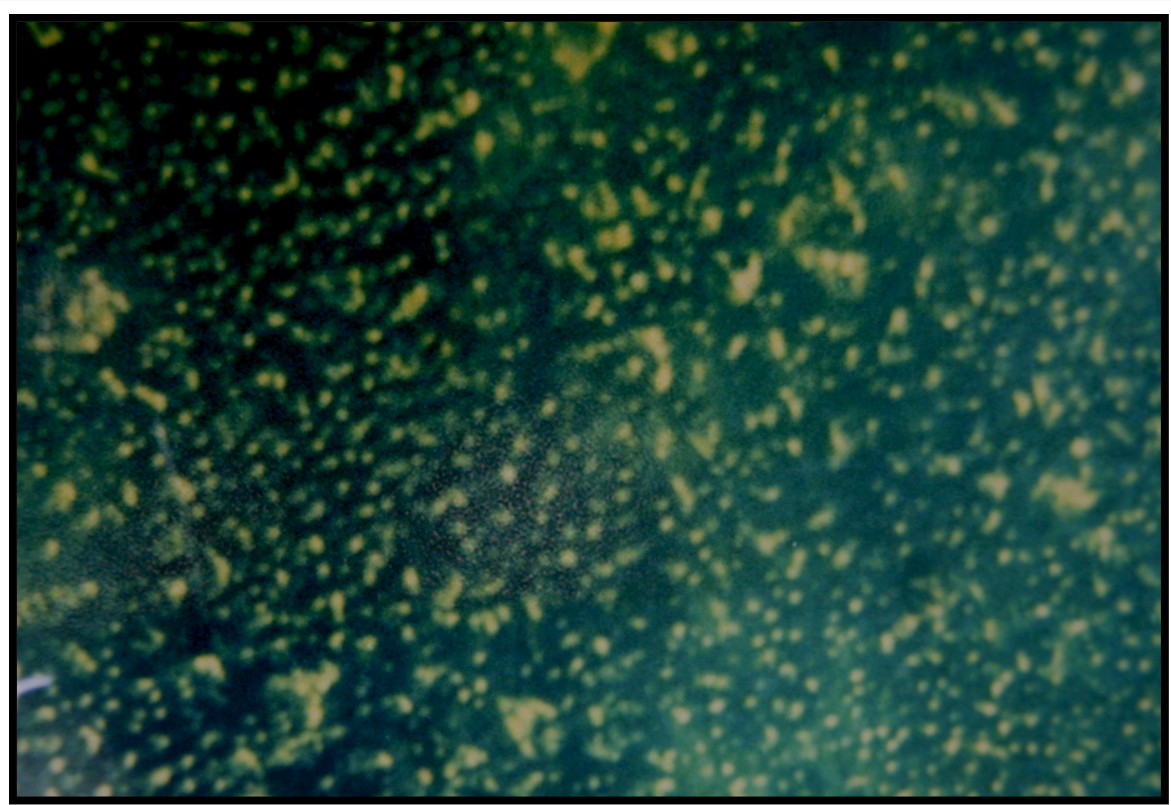

Fig(1): Positive FAT applied on viral antigens (4+) showing strong apple green fluorescent reaction $(100 x)$.

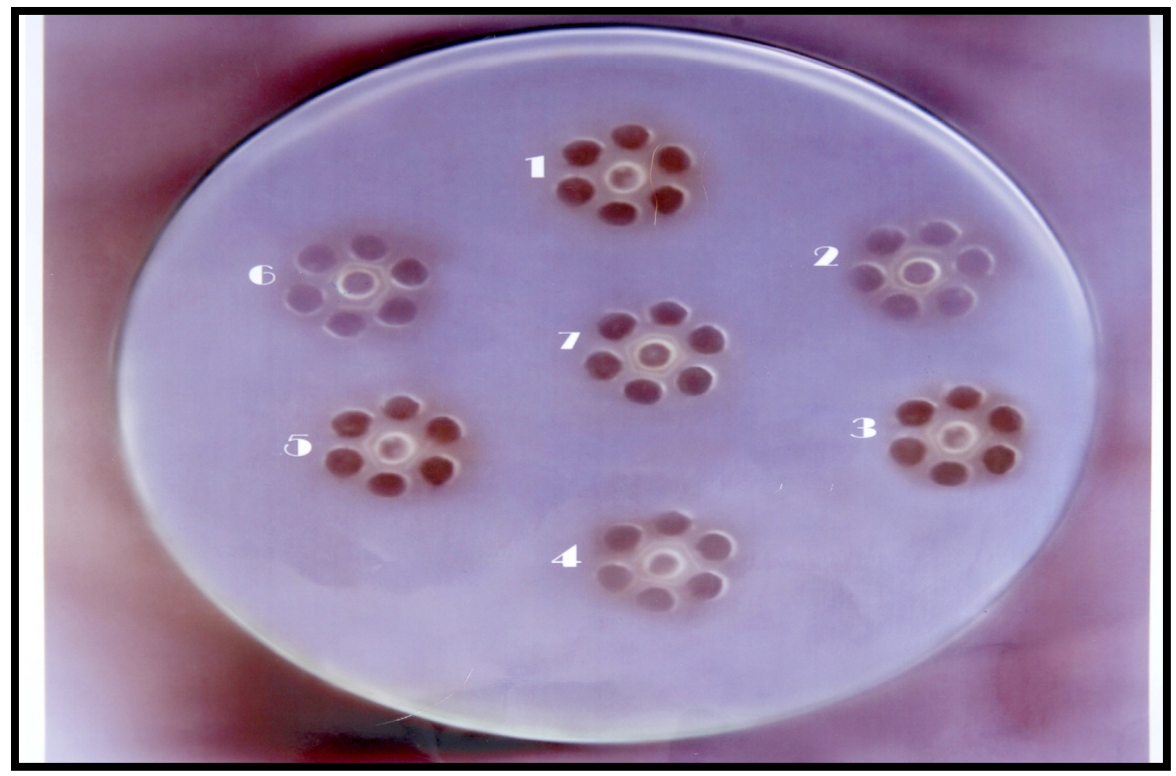

Fig (2): AGPT showing clear precipitation lines with positive sera.

Kafrelsheikh Vet. Med. J. Vol. 7 No. 1 (2009) 
During the present work different hosts were used for preparation of NDV; IBV and IBDV antisera in order to choose the best one from the quality and economic view.

The obtained results revealed that the prepared NDV antiserum had antibody titers of $9 \log 2 ; 8 \log 2$ and $8 \log 2$ in chicken serum; $8 \log 2 ; 7 \log 2$ and $8 \log 2$ in duck serum; $8 \log 2,7 \log 2$ and $7 \log 2$ in rabbit serum and $9 \log 2,9 \log 2$ and $7 \log 2$ in goat serum as estimated by HI, SNT and AGPT respectively showing that the highest titers were detected in chicken and goat sera as shown in (Table-1). These titers appear to be of high levels and approach to those of Box and Furamengen (1975) and supported by the findings of Ali and Abdul Aziz (1991) who showed that the fourth vaccination with ND vaccine increased the antibody titers.

Regarding IBV antibody titers were found to be $9 \log 2$ and $8 \log 2$ in chicken serum; $4 \log 2$ and $3 \log 2$ in duck serum; $8 \log 2$ and $6 \log 2$ in rabbit serum and $7 \log 2$ and $6 \log 2$ in goat serum as shown in (Table-2) as estimated by SNT and AGPT respectively, and this appeared to agree with Chubb and Cumming (1971) who recorded that Precipitin appeared regularly in infected birds and persisted for at least 3 months.

Concerning the IBD antiserum showed antibody titers of $8 \log 2$ in chicken serum; $7 \log 2$ and $6 \log 2$ in duck serum; $8 \log 2$ in rabbit serum and $7 \log 2$ in goat serum tabulated in (Table-3) by SNT and AGPT respectively. These results come in parallel with those reported by Hiari and Shamakura (1972) who recorded that. The precipitating antibodies were first detected 2 weeks after infection and stronger precipitin reaction was seen at 4 weeks after infection and similar to that reported by Abd El- Wanis and Khodeir (2004) who recorded that IBDV neutralizing antibody titers in the prepared hyper immune sera in 
different hosts (chicken, duck, and rabbit) were 1024, 256, and 128, respectively and higher than that recorded by Oladele et al (2004) who determined the presence of infectious bursal disease virus (IBDV) antibodies in village chickens in Oyo state, Nigeria, out of 392 sera tested, $248(63.3 \%)$ samples were positive with a titer rang of $\log 2$ to 4 $\log 2$.This difference in the titers could be attributed to increase antibodies formation in response to repeated vaccination.

In order to evaluate the prepared FITC conjugated antisera; the direct fluorescent antibody technique was carried on virus antigens and infected Vero cells. NDV-FITC conjugated antisera showed positive fluorescent apple green reactions up to a dilution of 1:10000 for chicken and duck conjugates and 1:100000 for rabbit and goat conjugates as shown in (Table-4).These results appeared to be higher that that reported by Gervelmeyer et al (1998) who reported that In the direct fluorescent antibody test the 1:4 or 1:8 in phosphate buffer saline diluted conjugates reacted specifically with their homologous antigen in the impression smear prepared from organs of experimentally infected chickens and in cover slip cell cultures when used vaccines containing inactivated Newcastle disease (ND), Infectious bronchitis (IB) and Infectious bursal disease (IBD) viruses. This disagreement could be attributed to repeated vaccination.

On the other hand the FITC conjugated anti-IBV sera showed positive reactions up to 1:10000 for chicken conjugate; 1:1000 for duck conjugate and 1:100000 for rabbit and goat conjugates as shown in (Table-5) .These results appeared to be higher than that recorded by Jones (1975) who mentioned that IFA titers were detectable as early as one week after IBV infection and persisted for at least 6 weeks. Titers 
never exceeded 1:64. This disagreement could be due to higher antibody levels in the prepared sera lead to use of high dilution of conjugated anti sera.

Regarding to the prepared anti IBD sera conjugated with FITC revealed positive reactions up to a dilution of 1:100000 for chicken; ducks and rabbit conjugates and 1:1000000 for goat conjugate as it is clear from (Table-6).Similar findings were described by $\boldsymbol{A b \boldsymbol { B }} \boldsymbol{E} \boldsymbol{l}$-Wanis and Khodeir (2004) who found that the prepared conjugates with (FITC) were able to detect the IBDV in different sites of infected eggs when they were diluted up to 1:105 giving strong, moderate or weak positive FAT according to the virus concentration in the tested sites.

Among the evaluation results of the prepared anti ND virus hyper immune serum conjugated with horse radish peroxidase using direct ELISA, it was found that positive results were obtained with conjugate dilution of 1: 500;1:400;1:500 and 1:400 for chicken; duck; rabbit and goat conjugates respectively, as shown in (Table-7).

IBV antisera conjugated with horse radish peroxidase showed positive results up to dilutions of 1:500 for chicken and rabbit conjugates and 1:400 for duck and goat conjugates as shown in (Table-8).

It was found that horse radish peroxidase Conjugated IBDV antisera showed positive results up to dilutions of 1:500 for chicken and rabbit sera and 1:400 for duck and goat sera, as shown in (Table-9). These results were lower than that reported by Marguardt et al (1979) who reported that the chromatographically purified rabbit anti chicken immunoglobulin-G conjugated with horse radish peroxidase was used optimally at dilution of 1:3000. 


\section{REFERENCES}

- Abd EL-Wanis, N.A.and Khodeir, M.H. (2004): Conjugation of immunoglobulins prepared against infectious bursal disease virus in different hosts with fluorescine isothiocyanate. Egypt.J.Agr. Res., 82(4):1881-1891.

- Ali, D. S. and Abdul-Aziz, T.A. (1991): Effect of repeated vaccination on the antibody response of broilers against Newcastle disease. Indian Journal of Animal Sciences, 61(4):357- 359.

- Allan, W.IL.; Lancaster, J. E. and Toth, B.(1978): Newcastle disease vaccines. Their production and use .FAO animal production and health series no.10.FAO .Rome.

- Box, P.G. and Furamengen, I.G.S. (1975): Newcastle disease antibody levels in chickens after vaccination with oil emulsion adjuvant killed vaccine, Vet . Rec . 96 NO 5, 108-111.

- Breitenfeld, P.M. and Schafer, W. (1957): The formation of fowl plague virus antigens in infected cells as studied with fluorescent antibodies. Virology, 4: 328-345.

- Brian, W.J. and Hiller, O.K. (1996): Virology Methods Manual Academic Press, New York, USA, PP: 108-110.

- Chubb, R.C.and Cumming, R. B. (1971): The use of gel diffusion precipitin technique with avian infectious bronchitis nephritis virus Australian. Vet .J.47(10): 496-499. 
- Cowan, K.M. and Graves, J.H.(1966): A third antigenic component associated with Foot and Mouth disease infection, Virology 30 :528540.

- Gervelmeyer, A; Abu-Ajamijeh, -H; Bani-Younis, -E; Anasweh, -O; Bzour, -N; Akasheh, -R; Clausen, -P -H; Staak, -C; Monreal,-G (1998): Production of virus specific egg yolk antibodies for the diagnosis of Newcastle disease, infectious bronchitis and Gumboro disease by the direct fluorescent antibody technique .Revue-dElevage-et-de- Medecine - Veterinaire-des-pays- Tropicaux 51(1) 5-9.

- Hiari, K. and Shamakura, S. (1972): Immunodiffusion reaction to avian infectious bursal disease virus Avian .Dis , 16 :961-965.

- Hubschle, O.J.; Lorenz, R.J. and Mathek, H.D. (1981): Enzyme linked immuno-sorbant assay for detection of blue tounge virus antigen. Am.J.Vet.Res.,42 :61-65.

- Ihemelandue, E.C.; Nduaka, O. and Ojukwa, E.M. (1985): Hyperimmune serum in the control of pest des petit ruminants. Trop. Anim. Heal. Prod. 17 (2): 83-88.

- Jones, R.C.(1975): Use of in direct FAT method for detecting antibodies to IBV in chickens serum .J. of Comp. Pathol. 85 (3): 473479.

- Lefevre, P.C. and Diallo, A. (1990): Pest des petit ruminants. 
- Marguardt, W.W.; Johnson, R.B.; Oden Wald, W. F. and Schlotthober, B. A. (1979): An in direct enzyme linked immuno sorbent assay (ELISA) for measuring antibodies in chicken infected with infectious bursal disease virus. Avian. Dis, 24 :375 -385.

- Narin, R.C. (1969): Fluorescent protein tracing. $3^{\text {rd }}$ Ed. Livingston Edinburgh and London.

- Narin, R. C. and Marrack, G. R. (1964): Fluorescent protein tracing $2^{\text {nd }}$ Ed . Livingston Edinburgh and London.

- Oladele,O.A.,Emikpe,-B-O; Oluwayelu, O-D; Ohore, -O-G. (2004): Comparison of agar gel precipitation test (AGPT)and enzyme linked immunosorbent assay (ELISA)in detection of infectious bursal disease virus (IBDV)antibodies in village chickens in Oyo state, Nigeria. Nigerian. Vet .J. 25(1):26-29.

- Rossiter, P.B.; Jesset, D.M. and Taylor, W.P. (1985): Microneutralization system for use with different strains of pest des petit ruminant's virus and rinderpest virus. Trop.Anim.Heal.Prod.,17 (2): 75-81.

- Singh, K.V.; Osman, O.A.; Thanaa, I.Baz and Ivon, El-Cicy (1967): Colostral transfer rinderpest neutralizing antibodies to offspring of vaccinated dams. Can. J. Comp. Med. Vet. Sci., 31: 295-298.

- Soliman, A.K.; Botros, B.A.M.; Rsiazek, T.G.; Hoogstreal, H.; Helmy, I. and Morin, A (1989): Sero-prevalence of Rickettsia typhosa and Rickettsia cornil infection among rodents and dogs in Egypt. Egypt. J. Trop. Med. Hyg. 92: 345-349. 
- Spendlove, R.S.; Lennette, E.H. and John, A.C. (1963): The role of mitotic apparatus in intracellular location of Reo virus antigen .J. Immunol. 90: 554-560.

- Tevethia, S.S.; Katz, M. and Rapp, F. (1965): New surface antigen in cells transformed Simian Papovirus SV40.Proc.Soc.Exp.Biol. (NY), 119: 896-901.

- Tijssen, P. and Kurstak, E. (1984): Highly efficient and simple methods for the preparation of peroxidase and active peroxidaseantibody conjugates for enzyme immunoassays. Analytical Biochem. 136: 451-457.

- Tizard, I.R. (1996): Veterinary immunology, $5^{\text {th }}$ Ed. Saunders Comp., Philadelphia.

- Voller, A.; Bidwell, D. E. and Bartlett, A. (1976): The enzyme linked immunosorbent assay (ELISA): A guide with abstracts of microplate applications. Dynatech Lab. Alex. Virginia.

- Weichselbaum, T.E. (1946): An accurate and rapid method for the detection of proteins small amounts of blood serum and plasma. Am. J. Clin. Path.16: 40-49.

- Yasumara, Y. and Kawatika, Y. (1963): Studies on SV40 in tissue culture.Nihon Rinsho, 21: 1201-1215. 
تحضير وتقييم كواشف تشخيصية لأمراض النيوكاسل والإلتهاب الشعبي المعدي وإلتهاب غدة فابريشس لومرام الئرك

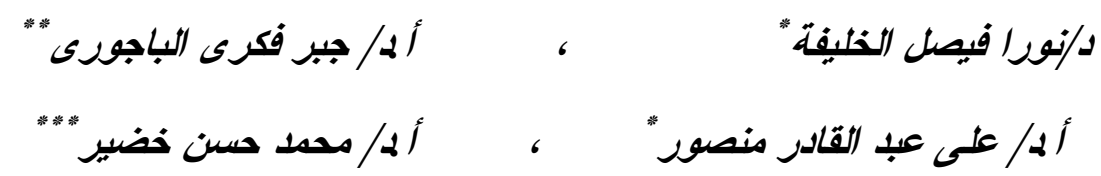

" كلية الطب البيطري - جامعة كفر الثيخ - " كلية الطب البيطرى - جامعة بنها " • معهل بحوث الأمصال و اللقاحات البيطرية- العباسية- القاهرة

صمدت الدراسة الحالية لتحضير أمصال نوعية مضادة لكل من فيروسات النيوكاسل و الإلتهاب الثعبي المعدي و الجمبورو (مرض غدة فابريثس المعدى) فى صور مفردة وصور مقترنة بمادة الفلوريسين أيزوثيوسينات و الهورس راديش بيروكسيديز لزوم التعريف بمعزولات الفيروسات الثثلثة سبرولوجيا بنطبيق أختبارات الفيروس المتعادل و الترسيب المناعى فى الأجارو الوميض الفلوريسنتى المناعى المباشر والأنزيم المرتبط المدص المناعى على أن تحضر هذه الأمصال فى عوائل مختلفة لاختيار الأنسب منها من حيث القيمة العيارية و التكلفة الاقتصادية لتكون متاحة وقتما ينطلب الأمر نوفير ا للوقت الذى قد يطول عند إستير اد متل هذه المو اد إضافة إلى توفير المال ففى الغالب ما يكون المثيل المستورد ذو قيمة عالية.

هذا وقد أوضحت النتائج أن المصل المضاد لفيروس النيوكاسل وجد أنه ذو معيار 9 و 8 ، 8 لو 2 للمصل المحضر فى الدجاج باختبار منع التلزن الدموى وأختبارى التزسيب فى الآجار و المصل المتعادل على التو الى.بينما كانت هذه القيم 8لو 2، 7لو 2 و 8لو 2 على التو الى للمصل المحضر فى البط وكانت منيلاتها 8لو 2، 7لو 2 و 7لو2 فى المصل الأرنبى و 9لو 2، 9لو 2و 7لو 2 فى المصل الماعزى على التو الى.أما الأمصال المضادة للإلتهاب الثعبى المعدى فقد أظهرت المعايير 9لو 2 و8لو 2 فى 
مصل الدجاج باختبار المصل المتعادل والترسيب فى الآجار على التوالى، 4لو 2 و 3لو 2 بنفس الأختبارين على التو الى فى المصل المحضر فى البط ، للو 2 و6لو 2 للمصل المتعادل و الترسيب فى الآجار تو اليا للمصل الأرنبى، 77 2 و6لو 2 على التو الى للمصل الماعزى. كما كان للمصل المضاد للجمبورو معايير باختبار المصل المتعادل و الترسيب فى الآجار 8لو 2 بكلا الأختبارين للمصل الاجاجى، 7لو 2 و 6لو 2 على التو الى للمصل المحضر فى البط، 8لو 2 و 7و 2 بكلا الاختبارين للمصل الأرنبى و الماعزى على النو الىى. - ملى

عند إجراء أختبار الوميض الفلوريسنتى المناعى على خلايا الزرع النسيجى المعدية بالفيروسات قيد التجربة أو أنتيجيناتها، أعطت الأمصال المضادة للنيوكاسل و المقترنة بالفلوريسين أيزوثيوسينات نتائج إيجابية حتى تخفيف 1: 10000 للأمصال المحضرة فى الدجاج و البط وحتى تخفيف 1: 100000 للأمصال المحضرة فى الأر انب والماعز و أظهرت الأمصال المضادة للالتهاب الثعبى المعدى و المقترنة بنفس المادة نتائج إيجابية حتى تخفيف 1: 10000 لأمصال الدجاج 1: 1000لمصل البط، 1: 100000لأمصال الأرانب والماعز0 كذلك تم الحصول على نتائج إيجابية للأمصال المقترنة المضادة للجمبورو حتى تخفيف 1: 100000 لأمصال الدجاج و البط وحتى تخفيف

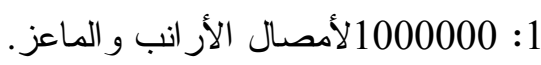

بتقييم الأمصال المقترنة بالهورس راديش بيروكسيديز باختبار الأنزيم المرنبط المناعى المدص وجد أن الأمصال المقترنة المضاد للنيوكاسل تعطى نتائج إيجابية حتى التخفيفات 1: 500، 1: 400، 1: 500، 1: 400 لأمصال الدجاج و البط والأرانب و الماعز على التو الى و أعطت أمصال الالتهاب الثعبى المعدى نتائج إيجابية حتى التخفيفات 1: 500 لأمصال الدجاج و الأر انب و 1: 400 لأمصال البط و الماعز كما تم الحصول على نتائج إيجابية لأمصال الجمبورو حتى تخفيف 1: 500 لأمصال الدجاج و الأرانب و 1: 400 لأمصال البط و الماعز . 